\title{
From Chaos to Coherence: Myles Brand and the Balancing of Academics and Athletics
}

\author{
John R. Thelin \\ University of Kentucky
}

In the United States we rely on colorful mascots to convey the real and imagined values associated with the heritage of our colleges and universities. If I were to select one of these to personify Myles Brand's place in higher education it would be the Gryphon. This legendary creature from Ancient Greek mythology was the guardian of light and was the fierce opponent of the darkness known as chaos. It's an apt match with Myles Brand because the Gryphon is one of the few members of the intercollegiate mascot menagerie who represents both cerebral and athletic prowess.

Symbols gain credibility when they are based on substance. An invaluable source to assure that combination in this essay is the comprehensive website providing archives and access to Myles Brand's papers that was launched in February 2021 (https://www.mylesbrand.com ). Its holdings offer an abundance of documents which will be essential for articles and analysis about him as a memorable colleague and influential higher education leader over several decades - yet, sadly, not long enough. My aim is to introduce those rich sources not to exhaust them. I leave intensive primary source research to a subsequent cohort of scholars who take higher education and public policy seriously.

As prelude and preface to this volume I wish to place Myles Brand's leadership roles into historical context, with particular attention to his perceptive response to the chemistry of the modern American university and the serious business of intercollegiate athletics over the span of several decades encompassing the late $20^{\text {th }}$ and early $21^{\text {st }}$ centuries.

Each generation of college and university presidents sees itself as cast into a particular and even peculiar set of headaches that comes with the office. In 1958, for example, Clark Kerr, famous as President of the University of California, noted that the modern university president's role was to be a mediator. He even noted with good humor that the administrative problems facing a modern university president often were reduced to "providing parking for faculty, sex for the students, and athletics for the alumni." Implicit in his analysis was that presidential mediation of this era took place in an environment of abundance where typically the financial decision was not to give or to cut funding for a dean. Rather, it was the delightful problem of whether to give - or give more (Kerr, 1958, p. 96). 
Four decades later the presidential concerns had changed drastically. In 1996, for example, the President of Cornell addressed a group of fellow presidents of prestigious universities and confided that their collective fate was that "Presidents are beggars who live in big houses" (Rhodes, 1996, p. 1). Philanthropy loomed large as raising money from donors was the inescapable task at all colleges and universities, whether rich or poor, in an era shaped by the construct and policies of privatization.

How explain the change in presidential casting from mediator to beggar? One reason for this new preoccupation for college and university presidents was that generous public support through state tax appropriations became uncertain and often tapered or declined in actual dollars, both because state tax revenues declined and citizen support for investment in higher education waned. The fifteen-year period starting in 1970 had been cited by economists as "the new depression in higher education." (Cheit, 1973, p. 1). For more than a decade colleges encountered a situation of "stagflation" - an unprecedented combination of double-digit inflation coupled with declining gross national income. The situation was sufficiently stark and prolonged that even prestigious historic institutions with large endowments such as Yale and Brown were showing deficits in their annual budgets.

Economist Charles Clotfelter perceptively noted that starting around 1985 a cluster of institutions signaled recovery from "Higher Education's New Depression" that had started in the 1970s and brought stagflation to all campuses for over a decade. But the financial recovery that started around 1982 gave some universities a combination of robust endowments and high academic prestige that opened the gates for them to "buy the best" - whether it be to attract a head coach, outstanding students, accomplished researchers, or a charismatic president (Clotfelter, 1996). The bubble of abundance burst, however, with the recession of 1989 which was followed by persistent academic budget cuts and austerity measures throughout the 1990s.

\section{Coming of Age in 1989: A Pivotal Year for American Higher Education and Myles Brand}

Myles Brand was professionally and personally caught in the middle of the presidential characterizations of the 1960 "mediator" and the 1996 "beggar who lived in a big house." However, to parse the chronological data more closely, the crucial year both for Myles Brand and for American higher education was 1989. Why was this confluence important? To flesh out these vital statistics about Myles Brand's career it is useful to look closely at the social, political, and economic trends in which he and other college and university presidents worked. The year 1989 represented the great divide.

In 1989 the United States economy was under stress, experiencing one of the sharpest, deepest declines in the stock market and leading to massive unemployment and declines in state revenues. The triple whammy was that it also put the brakes on generous private donations from several traditional sources - individuals, corporations, and foundations. Finally, the number of ascending research universities competing for federal grants from such agencies as the National Science Foundation and 
the National Institutes of Health increased while total available federal research and development funds were declining. All this was a shock to the national system - and to American higher education - because it marked the unravelling of a trend toward recovery and prosperity that had been ascending since 1985 .

This problematic situation and financial stress quickly became evident to Myles Brand when he was inaugurated as President of the University of Oregon in 1989 and then served until 1994. The state of Oregon's landmark tax cut measure known as Proposition Five cast Brand as president and the flagship state university into an unprecedented austerity, leading to dependency on private fund raising. And Brand did well with the Campaign for Oregon, raising \$235 million - at the time a record for the university.

As a new president Myles Brand was resourceful in responding to financial adversity with institutional policies and practices that benefitted overall institutional health. His plan was to simultaneously increase tuition revenues, add to undergraduate enrollments, and raise admissions standards at the University of Oregon. How did he accomplish this educational coup? He did so by launching an initiative to enhance recruitment of out-of-state students. This new, expanded constituency came primarily from California where many outstanding applicants were being turned away due to high enrollments at California's crowded campuses. The cohort of outof-state students tended to have strong high school academic records and test scores. Furthermore, they would pay relatively high out-of-state tuitions when they enrolled at the University of Oregon. President Brand convinced the Oregon State Board of Higher Education and its Chancellor of all state campuses to allow the University of Oregon exclusive claim to keep the added out-of-state tuition revenues. On balance, he had transformed a problem of scarcity into an effective educational strategy that enhanced the University of Oregon's national academic stature and institutional ranking.

\section{College Sports in 1989: Prospects and Problems}

The year that Myles Brand first became a university president - 1989 - coincidentally also was auspicious because it was the year of the founding of the Knight Commission on Intercollegiate Athletics. This was a watershed in marking the attention that many university presidents started to devote directly to curbing and controlling the excesses of college sports. It meant that intercollegiate athletics had moved "the sports page to the front page" (Thelin, 1994). And the headline news was not always good.

By 1980 a report commissioned by the American Council on Education concluded that college sports, especially in NCAA Division I, had become "The Money Game" (Atwell et al., 1980). The financial puzzle with this development was that big-time intercollegiate athletics programs were expected to be self-supporting yet there was little systematic tracking of financial data to monitor financial performance one way or the other. Within the environment of overall declining resources for colleges and universities in this era, achieving balanced budgets and self-supporting 
athletics departments became increasingly problematic even at NCAA Division I programs (Thelin \& Wiseman, 1990).

The peculiar economics of college sports was such that university varsity programs, instead of being net revenue producers, were net revenue users and not self-supporting. Traditional revenue sources (ticket sales, television, donations) are chronically short in generating enough income to support costly intercollegiate programs. During periods of rising costs, Division I athletic directors wanted to deal with the problem by trying to increase these revenues instead of decreasing costs. Since revenues were already difficult to increase appreciably, these strategies quickly created a revenue/cost gap. These same problems found that the most popular method of closing the revenue/cost gap was to increase donor solicitation. This persistent financial crisis created a need for universities to rethink the incorporated "athletic associations" within their institutions.

For Myles Brand, a defining feature of his leadership was to acknowledge the marriage of American higher education's odd couple of college education and competitive sports. Whereas a university president such as Clark Kerr in 1958 could be a mediator, for Myles Brand the challenge was to walk a tight rope while balancing academics and athletics. And this would continue the remainder of his career, both as President of Indiana University starting in 1994 and later, in 2003 when he was named President of the National Collegiate Athletic Association (NCAA).

\section{Success and Excess: A Chronology of Events and Developments in Intercollegiate Athletics}

Myles Brand became a university president at a crucial juncture in college sports. On the one hand, it marked the starting point of incredible commercial negotiations and partnerships. Foremost was the proliferation of television contracts for football at the level of conferences and individual institutions which were no longer confined by the NCAA's strict cartel that limited television broadcast rights. A second financial and public relations windfall was the flourishing of the Road to the Final Four and March Madness tournaments for men's basketball. This meant both a massive increase in ticket sales and attendance at tournament games as well as a new, expanded television viewing audience for men's basketball.

On the other hand, starting around 1989, various groups started and then persisted in serious reform discussions. As already noted briefly, one landmark was the creation of the Knight Commission - leading to hearings in Washington, D.C. in 1990 about the character and condition of college sports. Trite but true, it was the best of times and the worst of times. The three-decade period resembles match play of point then counter point. Each action prompted a comparable reaction in the following questionable areas:

- Academic Performance: Data on grade point averages and graduation rates raised questions about the status of student-athletes as genuine students, especially for those participating in the major revenue sports. Disparities in retention and graduation rates were especially pronounced for 
student-athletes who were minorities and from modest income families (Schulman \& Bowen, 2000; Levin \& Bowen, 2003).

- Financial Health: College sports continued to soar in media and broadcast popularity and revenues yet by 1989 distant early warnings indicated that even many big time college sports programs were running deficits. One convenient strategy adopted by many athletic directors was to reduce budgetary pressures by eliminating non-revenue Olympic sports, including women's varsity squads.

- In practices and policies involving gender and equity, the promising development was that Title IX had been passed in 1972 and, after initial resistance, the NCAA absorbed women's intercollegiate athletics under their sponsorship. Yet by the start of the $21^{\text {st }}$ century that sponsorship had not yet led to approximation of equity or accommodation. To the contrary, contentious lawsuits were brought by women student-athletes such as at Colgate and Brown. Opportunities for women in educational activities, including intercollegiate athletics, remained unfinished business by 2000 (Suggs, 2005; Thelin, 2000).

Among these troubling trends, perhaps most surprising, especially to sportswriters and media reporters who covered college sports, was the belated discovery by 1989 that most college sports programs lost money. An alarming and counter-intuitive finding was that this included many of the big-time conferences and university programs. Football, once heralded as the "golden goose" that would provide abundant funding for all sports, in fact was a money loser even within many NCAA Division I programs. Big-time sports programs which according to the NCAA guidelines were expected to be self-sufficient, frequently relied on cross-subsidies and bailouts from the university general fund. One irony was that the rate of spending on big time college sports increased at a higher rate than university spending on educational programs - even when college sports programs were running a deficit. The dominant big-time college sports model was broken - or, at very least in need of repairs and reforms.

\section{Details on the Knight Commission}

The paradox of popularity for college sports was that the successes at least in the commercial and popular arena led to problems on the campus. Illustrative of this coincidence or collision was the creation of the Knight Commission on Intercollegiate Athletics in 1989. It was an independent group with a professed commitment to leading reforms that were intended to strengthen the educational mission of college sports. The end game was to bring more and better attention to the student-athlete as the essential figure in the college sports enterprise.

According to documents and memoirs posted on the Knight Foundation website, the Commission was formed by the John S. and James L. Knight Foundation in October 1989 to recommend a reform agenda in response to highly visible athletics scandals and low graduation rates for college football and men's basketball play- 
ers that threatened the integrity of higher education. The Commission is composed of current and former university presidents and chancellors, university trustees and former college athletes, as well as nationally-regarded thought leaders from organizations with ties to or involvement in higher education or college sports (Knight Commission, 2021).

William C. Friday and Rev. Theodore Hesburgh, two icons in higher education, were the founding co-chairmen and provided leadership for the Commission's 1991 seminal report, "Keeping Faith with the Student-Athlete: A New Model for Intercollegiate Athletics." This report provided a roadmap for reform and was distributed to higher education leaders. It proposed a new "one-plus-three" model for governing intercollegiate athletics: presidential control directed toward academic integrity, financial integrity, and independent certification. By the late 1990s, the NCAA had considered many of the Commission's recommendations to strengthen academic standards and improve athletics governance.

Subsequent reports and recommendations continue to influence and contribute to positive change. Among the Commission's recommendations that led to policy changes: requiring teams to be on track to graduate at least 50 percent of their players to be eligible for NCAA postseason championships and bowl games; including academic incentives in the NCAA's revenue distribution plan; reducing athletics time demands on college athletes; and requiring coaches to disclose outside income from shoe and apparel companies. The Knight Commission also recommended that the NCAA should institute improvements to its coaching education programs and establish basic credentialing for coaches to ensure that coaches are prepared for their roles to protect the health, safety, and well-being of college athletes. The Knight Commission devoted energy and effort to reforming the governance of college sports. In the 1990s, for example, the Commission pushed for presidential leadership at the national, conference, and institutional levels.

\section{The Paradox of Problems and Prospects of College Sports}

A truism is that college sports are central to the life of American higher education. No other nation can cite let alone rival the place of varsity sports in the academic institution and enterprise. No American college or university states forthright that intercollegiate athletics are central to the mission of the institution. A customary characterization is for trustees to say that "After all, college sports are the front porch of the university."

Perhaps. But it is a very large front porch. It also is leaky and expensive to maintain and then to repair. The closest approximation to truth in advertising I have heard came about at a symposium sponsored by the Pew Charitable Trusts that brought together in Atlanta a gathering of academic and athletic leaders. The Commissioner of a powerful conference said with a straight face that perhaps it was time for some conferences and their member universities to state that college sports was, after all, part of their land grant mission. The claim was not persuasive even within the circle 
of college athletics leaders and advocates. The reality was that for many universities, Murray Sperber's description of "College Sports, Inc." meant that within NCAA Division I, the department of intercollegiate athletics often was comparable to a fiefdom or city-state, an incorporated body with privileged status and exemptions that made it simultaneously a part but apart from the university (Sperber, 1990).

Derek Bok, retired President of Harvard, placed college sports as a central source of concern in need of reform in the commercialization of higher education. The increasing presence of "universities in the marketplace" was especially conspicuous in the proliferation of selling naming rights and adopting logos from athletics donors along with manufacturers of sports shoes and uniforms. (Bok, 2003). Illustrative of this highly commercialized status were annual surveys conducted by USA Today that revealed in almost all states nationwide a state university head coach was the state employee with the highest compensation (Stebbins, 2020).

\section{Postscript: Myles Brand and a Legacy of Research and Discussion}

A staple datum in biographical profiles of Myles Brand is that he was the first President of the NCAA who had served as a university president. That is impressive but incomplete. An important addition to note is that he also was a pioneering NCAA President in that he was the first to have earned a $\mathrm{Ph} . \mathrm{D}$., gained tenure as a professor, and then served as an academic dean and provost prior to being inaugurated as a university president. This elaboration is not a quibble - because there is no assurance that a university president has scholarly bona fides in the curriculum vitae.

This profile of professional and academic roles also was consistent with one initiative Myles Brand championed early in his tenure as President of the NCAA. He advocated for creation of a research advisory council, consisting of appointment of several established scholars from a variety of disciplines - with the common thread that whether economists, philosophers, sociologists, psychologists, or historians they all studied college sports issues seriously and systematically. This forum of scholars was charged with conducting an annual scholarly colloquium at the start of the NCAA conference and also was responsible for overseeing the founding of the Journal of Intercollegiate Sport. These initiatives were exemplary as a model for timely active scholarship. As such they fulfilled the letter and spirit of the mythical Gryphon showcased at the start of this essay as they showed how the structure and spirit of critical analysis could illuminate essential issues and help to lead intercollegiate athletics away from chaos, edging toward coherence.

\section{References}

Atwell, R., Grimes, B., \& Lopiano, D. (1980). The money game: Financing college athletics. American Council on Education.

Bok, D. (2003). Universities in the marketplace: The commercialization of higher education. Princeton University Press. 
Bowen, W.G., \& Shapiro, H. (Eds.). (1998). Universities and their leadership. Princeton University Press.

Cheit, E.F. (1973). The new depression in higher education: A study of the financial condition at forty-one colleges and universities. MacMillan.

Clotfelter, C.T. (1996). Buying the best: Cost escalation in elite higher education. Princeton University Press.

Kerr, C. (1958, November 17). Education: View from the bridge. Time magazine. http://content.time.com/time/subscriber/article/0,33009,810691,00.html

Knight Commission on Intercollegiate Athletics (2021, May). https://www.knightcommission.org/

Levin, S., \& Bowen, W.G. (2003). Reclaiming the game: College sports and educational values. Princeton University Press.

MylesBrand.com. (2021, February). About Myles Brand. https://mylesbrand.com/ about-myles-brand

Rhodes, Frank T. (1966, March 26). The university and its critics. Paper presented at the Princeton Conference on Higher Education.

Schulman, J., \& Bowen, W.G. (2000). The game of life: College sports and educational values. Princeton University Press.

Sperber, M. (1990). College sports, Inc.: The athletic department vs. the university. Henry Holt.

Stebbins, S. (2020, Sept. 23). College coaches dominate list of highest-paid public employees with seven-digit salaries. USA Today. https://www.usatoday.com/ story/money/2020/09/23/these-are-the-highest-paid-public-employees-in-every-state/114091534/

Suggs, W. (2005). A place on the team: The triumph and tragedy of Title IX. Princeton University Press.

Thelin, J. R. (1994). Games colleges play: Scandal and reform in intercollegiate athletics. Johns Hopkins University Press.

Thelin, J. (July-August, 2000). Good sports?: Historical perspectives on the political economy of college sports in the era of Title IX, 1972 to 1997. Journal of Higher Education, 71, 391-410.

Thelin, J.R., \& Wiseman, L.L. (February, 1990). Fiscal fitness? The peculiar economics of intercollegiate athletics. Capital Ideas, 4(7), 2-13. 